\title{
AWANGARDOWE ODDŹWIĘKI ANNY ŚWIRSZCZYŃSKIEJ WIERSZE I PROZY POETYCKIE $Z$ LAT TRZYDZIESTYCH XX WIEKU
}

Wiersze i proza, debiutancki tom poetycki Anny Świrszczyńskiej, został wydany nakładem autorki w roku 1936; drugi zbiór ukazał się dopiero po 20 przeszło latach. W Lirykach zebranych (1958) poetka w przejmującym poemacie Rok 1941, wypowiadając się zarówno w imieniu własnym, jak i w imieniu mieszkańców kraju ogarniętego wojną (a w nieco węższej perspektywie - miasta/stolicy), oświadcza kategorycznie, gorzko:

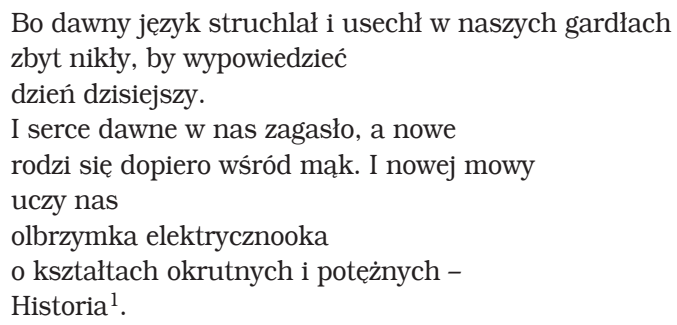

Wojna zagłuszyła niegdysiejsze dykcje, język opisujący wcześniejszą rzeczywistość stał się niewystarczający, okazał się bezużyteczny, za słaby, zbyt wątły, nieadekwatny do teraźniejszych wydarzeń. Wraz z nim zniknęła poprzednia uczuciowość, zgasły emocje nie naznaczone przemocą. Nie doprowadziło to jednak do powstania pustki. W miejsce tego, co było, wkroczyła Historia; jej lekcje okazały się zaś niełatwe i nierzadko pociagały za sobą liczne ofiary.

Dlaczego przywołuję akurat ten fragment? Otóż zawarta w nim diagnoza uprzytamnia, że to, co było kiedyś, zostało radykalnie - choć przecież nie dobrowolnie pozbawione szans na rozwój, jako zbyt delikatne, nietrwałe i mało odporne w obliczu grozy. Innymi słowy, Świrszczyńska, diagnozując wojenną teraźniejszość, wskazuje również (pośrednio) na kryzys poezji, oznaczający nie tylko konieczność wypracowania nowego języka, lecz przede wszystkim kres znacznej części (większości? wszystkich?) dykcji poetyckich, tak intensywnie rozwijających się w Dwudziestoleciu.

Ważnym ogniwem dynamicznego rozrostu ówczesnej liryki są także Wiersze i proza, podzielone na trzy - na pierwszy rzut oka odmienne, niemniej przy bliższym 
oglądzie, kompatybilne - części. W rozmaitych proporcjach łączą się w nich ze sobą elementy bliskie dykcji skamandryckiej i awangardowej (obejmującej też futuryzm i surrealizm), ale również, co najważniejsze, rozwiązania formalne zaproponowane przez Świrszczyńską jako idiomatyczne, podkreślające jej odrębność, wskazujące na oryginalność i samodzielność myślenia poetyckiego. Wszystkie te cechy są sygnałami dojrzałości dykcji lirycznej, widocznej już w debiutanckich tekstach przyszłej autorki jednego $z$ najciekawszych powojennych tomów (Jestem baba), a ponadto przypominają o interesującej cesze poezji kobiet $z$ Dwudziestolecia międzywojennego. Mam na myśli specyficzną osobność, by nie rzec: izolację czy dystansowanie się od działań grupowych. Precyzyjnie opisała ten gest Agata Zawiszewska, widząc jego symptom już w trzeciej dekadzie XX wieku:

W latach dwudziestych poetki nie brały udziału w zjawisku grupowego wyrażania własnych dążeń twórczych, wchodziły do literatury zawsze w pojedynkę, przemawiały wyłącznie we własnym imieniu, nie budowały aliansów i opozycji, nie tworzyły programów ani jako projekcji czy dopełnienia własnej praktyki poetyckiej, ani jako działalności samodzielnej, od tej praktyki niezależnej. [...] Na tle żywiołowej działalności grup męskich, powiązanych wolą wspólnego działania, spójną koncepcją roli poezji i poety w społeczeństwie oraz rozpoznawalnym stylem twórczości, kobiety poetki to samotne wyspy, które nie komunikują się ani $z$ innymi kobietami, ani z mężczyznami piszącymi $[\ldots]^{2}$.

Awersję do zrzeszania się, przyłączania do mniej lub bardziej formalnych grup czy też do ogłaszania wyrazistego programu, funkcjonującego jako mocna deklaracja i (meta)komentarz do własnej twórczości, Świrszczyńska potwierdziła po latach:

Nie należałam świadomie do żadnego ówczesnego kierunku poetyckiego. Do poezji, która wtedy panowała nagminnie na łamach pism literackich, byłam praktycznie w opozycji, raził mnie modny wówczas przerost metafory, której ja prawie zupełnie nie używałam, raziło rozwichrzenie i wielomównośćs.

Z biegiem lat owa niechęć osłabła, aby w końcu okazać się radykalnie zbędną. Otóż Świrszczyńska, podobnie jak inne poetki mniej lub bardziej wyraziście zaznaczające swoją obecność na lirycznej scenie między 1918 a 1939 rokiem, funkcjonowała nieco na prawach wyjątku od reguły, za jaka uchodziła poezja uprawiana przez mężczyzn, stanowiąca odnośnik dla osób próbujących scharakteryzować czy

2 A. Zawiszews ka, Między Młoda Polska, Skamandrem i Awangarda. Kobiety piszace wiersze $w$ Dwudziestoleciu międzywojennym. Szczecin 2014, s. 250. O miejscu twórczości Świrszczyńskiej na mapie poezji kobiecej, jak również o jej specyfice, zob. także M. B a r a n ow s ka, Szymborska i Świrszczyńska - dwa bieguny codzienności. „Teksty Drugie” 1995, nr 3/4. - G. B o r k ow s k a, Metafora drożdży. Co to jest literatura/poezja kobieca. Jw. - B. M a j, „Mówić biegle językiem cierpienia". O poezji Anny Świrszczyńskiej. W zb.: Lektury polonistyczne. Literatura współczesna. Red. R. Ny c z. T. 2. Kraków 1999. - A. Le ge ży ń s ka, Od kochanki do psalmistki... Sylwetki, tematy $i$ konwencje liryki kobiecej. Poznań 2009. - A. G a je w s k a, Prywatne/publiczne/pacyfistyczne $w$ poezji Anny Świrszczyńskiej. W zb.: Pisarstwo kobiet pomiędzy dwoma dwudziestoleciami. Red. I. Iwasiów, A. Galant. Kraków 2011. - J. Za ch, Anna Świrszczyńska: między estetyka kreacyjna a mimesis. W zb.: Formacja 1910. Świadkowie nowoczesności. Red. D. Ko zicka, T. Ci i śla k - S o k oł ow s ki. Kraków 2011. - Polskie pisarstwo kobiet w wieku XX: procesy igatunki, sytuacje i tematy. Red. E. Kraskowska, B. Kaniewska. Poznań 2015. - J. G rąd zi el-W ój c i k, Przymiarki do istnienia. Watki i tematy poezji kobiet XX i XXI wieku. Poznań 2016.

3 W. P. Szy mań s ki, Rozmowa z Anna Świrszczyńska. W: Rozmowy z pisarzami. Kraków 1981, s. 91. 
sklasyfikować - np. w antologiach - poezję kobiet. Zawiszewska zaznacza, że dokonując podziałów, „sami uczestnicy międzywojennego życia literackiego używali androcentrycznych kryteriów porządkujących ówczesną produkcję poetycką, które nie pozwalały im zrozumieć, co mówią o literaturze i kulturze polskiej utwory zapomnianych dziś kobiet piszacych [...]"4.

Świrszczyńska, debiutując w latach trzydziestych XX wieku (podobnie jak np. Zuzanna Ginczanka), miała już do dyspozycji wzorzec (traktowany jako możliwy, a nie konieczny): dobrze okrzepnięta poetykę Skamandra (szczególnie jeśli idzie o ważnego dla piszących kobiet Juliana Tuwima ${ }^{5}$; dodałabym tu jeszcze Jarosława Iwaszkiewicza ${ }^{6}$. Nie czerpała $z$ niej pełnymi garściami - idiomatyczność jej debiutu dominuje bowiem wyraźnie nad ewentualnymi pokrewieństwami - lecz wybierała to, co było dla niej ważne, czyli echa romantyzmu i modernizmu, ludyczność, anegdotyczność, skupianie się na codzienności (specyficznie rozumianej, choć czasami nieco groteskowej - co szczególnie dobrze widać w ostatniej części tomu, w prozach poetyckich), nie stroniła również od puent, błyskotliwie podsumowujących, a nierzadko podważających, wiersz lub prozę poetycką ${ }^{7}$. Ściślejsze bądź luźniejsze związki poezji kobiet (a więc i Świrszczyńskiej) z modelem skamandryckim i tak sa, według Zawiszewskiej, intensywniejsze niż związki z modelem awangardowym. Dlaczego?

Awangardowe dykcje domagały się większej sprawności formalnej oraz umiejętności krytycznego odnoszenia się do szeroko pojętej tradycji literackiej, a tej z racji ciagle jednak nierównego dostępu kobiet do edukacji - nie mogły znać poetki tak dobrze jak uprzywilejowani mężczyźni. Świrszczyńska (podobnie jak Ginczanka) jako absolwentka filologii polskiej wyłamuje się skutecznie $z$ tego, skądinąd w dużej mierze słusznego, uogólnienia - jej poezja jest także zaprzeczeniem, a mówiąc nieco łagodniej: dającym do myślenia dopowiedzeniem mocnej tezy o „nieobecności poetek w nurtach awangardowych, ekspresjonizmie, futuryzmie, kręgu Tadeusza Peipera, Juliana Przybosia, Józefa Czechowicza"8. Owszem, formalnie nie zrzeszona, wmontowała w swój debiut elementy dialogu $z$ obiema wyrazistymi poetykami. Dołączając do niego także futurystyczne odpryski, inkrustując go surrealistycznymi rekwizytami, stworzyła amalgamat, w którym funkcję spajającą pełnia groteskowość i nierzadko markowany tylko, niemniej widoczny, a przez swoja nieuchwytność bardziej przekonujący katastrofizm. Nie bez znaczenia dla wyjątkowości Wierszy i próz, szybko po publikacji „uznanych w środowisku literackim za wydarzenie" ${ }^{9}$, jest ewidentna skłonność poetki do sięgania po malarstwo jako inspirację dla lirycznej wyobraźni wyłaniającej się z eklektycznego, pozornie mało spójnego wewnętrznie tomu, odstającego (w sensie pozytywnym) od twórczości kolegów - skamandrytów czy awangardzistów. Czesław Miłosz podkreślał, że

Zaw is zew ska, op. cit., s. 205.

Zob. ibidem, s. 218.

Zob. Cz. Miło s z, Jakiegoż to gościa mieliśmy. O Annie Świrszczyńskiej. Kraków 1996, s. 44-46.

Zob. Zawiszewska, op. cit., s. 239. Co ważne, badaczka podkreśla, że puenty są punktem, w którym widać przeciwstawianie się awangardowym niedomknięciom czy rozwiniętej metaforyce. Ibidem, s. 240.

9 Cz. Miłosz, przedmowa w: A. Świr szczyńska, Poezja. Wybór Cz. Miłosz. Warszawa 1997, s. 6. 
autorce, choć znane i bliskie, obie zauważalnie zróżnicowane poetyki nie wystarczały, dlatego też szukała ona formy odpowiedniej dla swojej twórczości, formy za każdym razem modyfikowanej, udatnie dopasowanej do treści ${ }^{10}$, w różnym stopniu opierającej się na osobistych doświadczeniach Świrszczyńskiej. Przytoczmy jej własne słowa:

O kosztownych i czasochłonnych studiach malarskich nie mogło być mowy. Postanowiłam z żalem ograniczyć się do pisania.

Polonistyka przyniosła mi olśnienie barokiem i najstarszą polszczyzną, która pociagała mnie już w szkole średniej. Do dziś uważam polski język XV wieku za najpiękniejszy. Każde słowo jest tu dla mnie poematem, każde najprostsze zdanie mnie urzeka. Odkrycie baroku, które odbiło się silnie na moim debiutanckim tomiku Wiersze $i$ proza, zawdzięczam niezapomnianym seminariom $\mathrm{u}$ dr Zofii Szmydtowej.

Mój pierwszy tomik to właściwie obrazy malowane słowem. Patronowali mu - obok pisarzy - starzy znajomi z reprodukcji ojca. Pomieszali się w nim Rimbaud, El Greco i Dürer, Samuel Twardowski i Rousseau Celnik, Boska Komedia i Chirico. Nie przedarło się do tych wierszy nic ze smutnych przeżyć mojego dzieciństwa, nic z mego ówczesnego osobistego życia. Krytyk chwalił dyskrecję autorki, która tak starannie ukryła się za swoje słowa. Pod tym względem byłam przez długi czas nieodrodną córką swego ojca ${ }^{11}$.

Ojciec Anny, Jan Świerczyński, był malarzem tworzącym w duchu historycznym, ale i sięgającym po rozwiązania proponowane przez kubizm. Dzieciństwo przyszła poetka utożsamiała $z$ jego warszawską pracownią, w której pełno było skończonych lub właśnie malowanych obrazów, wielkich projektów witraży, studiów i szkiców z różnych epok. Świerczyńscy borykali się z niedostatkiem, od którego Anna uciekała w świat sztuki, przeglądając liczne albumy z reprodukcjami dzieł malarskich. Stąd zapewne wziął się pomysł dziewczyny, by studiować na Akademii Sztuk Pięknych - nigdy nie wprowadzony w życie $z$ powodu szczupłości środków, znalazł on realizację $\mathrm{w}$ zapoznawaniu się $\mathrm{z}$ malarstwem $\mathrm{z}$ ojcowskich książek i w pisaniu, a potem w szkicach o malowaniu ${ }^{12}$. Podkreślić warto, że wśród lektur ważnych dla kształtowania się jej późniejszej twórczości Świrszczyńska wymienia m.in. „Chimerę”, z drukowanymi w niej tekstami Cypriana Norwida, i „Skamandra”, ponadto zaś książki Maurice’a Maeterlincka, sąsiadujące z utworami Siergieja Jesienina czy z rozprawami o Buddzie. Do tej zróżnicowanej grupy poetka dodała również Nuż $w$ bżuhu - czyli futurystyczne eksperymentowanie (nie tylko) $z$ jezzykiem ${ }^{13}$. Rekonstrukcja biografii, siłą rzeczy skrótowa, potrzebna jest, aby przypomnieć o miejscu, jakie na mapie literatury Dwudziestolecia międzywojennego zajęła poetka, przedstawicielka formacji 1910 (ur. w 1909 r.), publikująca jeszcze przed oficjalnym debiutem książkowym z 1936 roku ${ }^{14}$.

Ibidem, s. 7-8.

A. Świrszczyńska, wstęp w: jw., s. 20.

Zob. Miłosz, przedmowa, s. 5-6. Biografię Świrszczyńskiej (takie brzmienie nazwiska zostało mylnie zapisane w księdze metrykalnej, co z perspektywy krytycznofeministycznej można odczytać dwojako - jako symboliczne pozbawienie jej przynależności do konkretnej rodziny oraz jako niezamierzony gest emancypacyjny: poetka nigdy nie skorygowała pomyłki, miała więc nazwisko własne, tj. nie będące nazwiskiem ojca, nie idące w linii „po mieczu”) rekonstruują także R. Stawowy, A. Stapkiewicz i W. Bojda, na które powołuję się w niniejszym artykule.

Zob. Świrszczyńska, wstęp, s. 19.

Początki działalności literackiej precyzyjnie odtworzyła W. Boj da (Anny Świrszczyńskiej odkry- 
Precyzyjnie ulokowała Świrszczyńską na wspomnianej - imaginacyjnej i kulturowo silnie uwarunkowanej - mapie Joanna Zach, zaczepiajac jej biografię o dwa silne filary. Pierwszym $z$ nich jest przeżycie pokoleniowe, czyli wielki kryzys europejski, który rozpoczął się w drugiej połowie lat dwudziestych XX wieku i który, choć początkowo miał charakter głównie finansowy, przełożył się także na podejście do sztuki jako takiej, czy jeszcze szerzej: do rzeczywistości w ogóle. Drugi z filarów to oczywiście druga wojna światowa i jej konsekwencje. Dla debiutu kluczowe znaczenie ma pierwszy z wymienionych ${ }^{15}$. Zach słusznie przypomina, że gdy Świrszczyńska objawiła się jako pełnoprawna poetka, istotne było oddziaływanie Awangardy Krakowskiej, która już musiała się liczyć z coraz szybciej zmieniającymi się warunkami historycznymi i politycznymi. Poetka swoją koncepcję liryki, tak silnie spowinowacona ze sztuka, rozgrywała subtelnie, metodycznie oraz zdecydowanie, pracując na materiale zapewniającym jej mocne zakorzenienie $\mathrm{w}$ tak cennej dla niej kulturze - zarówno wcześniejszej, np. średniowiecznej, jak i współczesnej. Zadomowienie w sztuce zapewniało Świrszczyńskiej niemalże niewyczerpane źródło inspiracji, połaczone $z$ inteligentnym, ironicznym, zawsze entuzjastycznym podejściem ${ }^{16}$, w którym humor sąsiadował często $z$ gorzkawym przeczuciem bliżej nie określonej katastrofy. Widoczna szczególnie w pierwszej i drugiej części Wierszy i próz skłonność do ekfrastyczności, balansującej na granicy między całkiem udatnie fingowanym realizmem a błyskotliwą, łamiaca patos groteska, oznacza przywiązanie do przeszłości, traktowanej jako archiwum tematów, wątków, odniesień, w teraźniejszości aktywowanych na zasadzie nieraz odległych powinowactw. Towarzyszy im skamandrycka $z$ ducha witalność ${ }^{17}$, koncentracja na codzienności, egzystencji zwykłych ludzi, z której można wydobyć liryczny pierwiastek, bez śladu górnolotności i bez poczucia wyższości. Dobrym przykładem będzie tu liryk Droga:

wanie rzeczywistości. Katowice 2016, s. 13, 80, 107-108), która przypomniała, że już w 1930 roku w „Płomyku”, a więc w piśmie przeznaczonym dla dzieci i młodzieży, ukazały się dwa wiersze Świrszczyńskiej - Śnieg i Szopka, a w 1934 roku J. Broniewska pisała o młodej poetce jako „od lat znanej i uznanej”, umieszczając ją obok E. Szelburg-Zarembiny i M. Kownackiej (ibidem, s. 80). Za datę debiutu „dla dorosłych” uznano właśnie rok 1934, kiedy w „Wiadomościach Literackich” został przedrukowany wiersz Południe, który $n b$. wszedł później do rozpatrywanego tu zbioru liryków. Precyzując, wzmiankowany wiersz został przez Świrszczyńską zgłoszony na konkurs pilotowany przez redakcję „Wiadomości”: „W Turnieju Młodych Poetów wzięło udział około tysiąca początkujących literatów. Toteż jury, w skład którego wchodziły skamandryckie sławy - Baliński, Tuwim, Wierzyński, Napierski, Podhorski-Okołów - włożyć musiało dużo pracy, by przebrnać przez stosy nadesłanych propozycji [...]" (ibidem, s. 108). Laureatów było troje - T. Hollender, W. Husarski i Świrszczyńska. Zwycięski wiersz zapewnił poetce przyjęcie do Związku Literatów w Warszawie. Zob. Za c h, op. cit., s. 348-349.

16 Zob. ibidem, s. 352. Zach (ibidem) podkreśla także: „Obrazy Świrszczyńskiej snują się same, wywiedzione $z$ malarskich inspiracji, zachowują wyrazistość pierwowzoru, a zarazem stają się przedmiotem intersemiotycznej gry i zabawy słownej, "która ma cel swój, acz o wszystko trąca". Tym celem może być scalanie świata kultury, w którym poszczególne sztuki i konkretne dzieła sztuki spotykają się na głębszym poziomie i obiektywizują się niejako w kontakcie ze sobą. Pierwszy tomik Świrszczyńskiej jest owocem dojrzałej kontemplacji, swoistego zanurzenia w świecie sztuki, którym ona oddycha w sposób naturalny, bezwiedny - bez cienia wysiłku czy kulturalnego snobizmu”.

17 O skamandryckich nawiązaniach w debiutanckim tomiku Świrszczyńskiej zob. Bojda, op. cit., s. 177-195. 
Kobiety na obfitych wzgórzach, dojrzałe gdy wieje przepyszny wiatr,

obnażone dzieci koło furtek,

zamknięte same w sobie, doskonałe,

i droga, która przepływa to wszystko - karety, konnica, pogodny nadmiar i ruchliwość obok chłopa, co pracuje w polu,

zbierając rzepę.

(Droga. W 32) $^{18}$

Wyrazistość liryki Świrszczyńskiej i wpisane w nią immanentnie założenia programowe stanowily konsekwencję wypracowanych w Dwudziestoleciu sposobów kształtowania ekspresji poetyckiej. Połączenie zwięzłości, dynamiczności, konkretów z enigmatycznością, spowolnieniem przechodzącym w bezruch, czułości z przeczuciem katastrofy, groteski $\mathrm{z}$ dobitnym realizmem już w debiutanckim tomiku zyskało wyjątkowo zwartą i dopracowaną formę. Owo skomplikowanie zostało dostrzeżone przez krytykę, w przeważającej mierze wypowiadającej się o tryptyku Świrszczyńskiej ${ }^{19}$ przynajmniej aprobatywnie, jeśli nie ze sporym entuzjazmem, niezależnie od przyjętej perspektywy - część komentatorów skupiała się tylko na recenzowanym tekście, starając się wydobyć jego właściwości, część próbowała umieścić go w szerszym kontekście, np. zestawiając $\mathrm{z}$ innymi wydanymi wtedy tomami, wskazując elementy wspólne, sygnalizując także potencjalne niebezpieczeństwa utrzymania wypracowanej w debiucie poetyki ${ }^{20}$.

Józef Czechowicz pisał z przekonaniem, że pierwszy tom Świrszczyńskiej nie ma w najmniejszym stopniu charakteru literackiej przygrywki ani lirycznego preludium, ponieważ jest w pełni dojrzałą formą, którą trudno wartościować inaczej niż pozytywnie. Poeta proponuje więc wyliczenie, a następnie krótką charakterystykę kilku cech, najlepiej według niego opisujących Wiersze i prozę. Zaczyna od „filiacji z malarstwem”21 (to nie tylko element formalny, gdyż wynika on z biografii autorki, jest $z$ nią ściśle spojony), precyzyjnie wskazując wzajemne zależności i wpływanie na siebie słów oraz implikowanych przez nie obrazów:

Niemal każdy wiersz poetki jest tematycznie związany ze sztuką plastyczną, najczęściej z malarstwem. Wszystko, co zawiera się w tych utworach poetyckich, albo dałoby się odtworzyć na płótnie, albo też odwrotnie, wygląda jak transpozycja dzieła malarskiego w materiale słownym ${ }^{22}$.

Czechowicz dodaje, że opisy często zawierają motywy zaczerpnięte ze sztuki średniowiecznej, nasyconej licznymi odniesieniami do Biblii, bez ortodoksyjnej jej wierności, lecz z dbałością o zachowanie proporcji między spokojem, lekkością, pewną sielankowością a delikatnym (choć stanowczym) sygnalizowaniem osuwania

Skrót W odsyła do: A. Świrszczyńska, Wiersze i proza. Warszawa 1936. Liczba po skrócie wskazuje stronicę.

Debiut Świrszczyńskiej jako tryptyk interpretuje Bojda (op. cit.). Inne monografie dotyczące twórczości autorki tomu Szczęśliwa jak psi ogon, w których wiele miejsca poświęcono przypomnieniu recepcji krytycznej pierwszego zbioru liryki poetki, to: R. Stawowy, „Gdzie jestem ja sama”. O poezji Anny Świrszczyńskiej. Kraków 2004. - A. S ta p ki e w i c z, Ciało, kobiecość i śmiech w poezji Anny Świrszczyńskiej. Kraków 2014.

Kulisy recepcji krytycznej skrzętnie odtwarza B ojda (op. cit.).

J. Cze ch owi cz, Anna Świrszczyńska: „Wiersze i proza”. W: Wyobraźnia stwarzająca. Szkice literackie. Wybór, wstęp, oprac. T. Kła k. Lublin 1972, s. 186.

Ibidem. 
się przedstawień w wieczność, poza czas i przestrzeń. Druga ważna cecha poezji Świrszczyńskiej opisana w recenzji Czechowicza to archaizacja, bez większego wysiłku dostrzegalna w warstwie językowej (składnia i fleksja), która wszak przekłada się na obrazowanie ${ }^{23}$. Następnie uwaga zostaje skierowana na szeroko pojętą treść wierszy - poeta akcentuje jej widoczną na pierwszy rzut oka szczupłość, niepozorność - ciasno splecioną z literackością najwyższej klasy. Przybiera ona formę stwierdzeń ${ }^{24}$, obwieszczeń, konstatacji, podanych w nierzadko wysublimowanych, misternych wersjach. Czwarta cecha ${ }^{25}$ łączy się z pierwszą, jest jej konsekwencją, pozwala tymczasem na koncentrację nie tyle na tekście, ile na postawie autorki wobec niego, przekłada się na konstrukcję podmiotu lirycznego:

Świrszczyńska pisze, mieszając archaizacje z ultranowoczesnymi wyrażeniami, dając obrazy naiwne, przeszyte tu i ówdzie jakimś słówkiem świadczącym, że ta naiwność nie jest bynajmniej jej stanowiskiem. Wydaje $z$ siebie światy soczyste i krzyczące barwami, ale ma pozycję poza nimi, poza czasem istniejącym w tych światach i ani na chwilę nie można pomyśleć o utożsamieniu autorki z jej twórczoś$\operatorname{cia}^{26}$.

Ostatnie stwierdzenie dziś budzi sprzeciw, gdyż nie można w żaden sposób pominąc autobiograficznego komponentu debiutu Świrszczyńskiej. Owa autobiograficzność jest skrzętnie ukrywana, transformowana w tak chwalony przez krytyków dystans. Myślę jednakowoż, że ów dystans nie powstał wyłącznie w wyniku dyskrecji czy zamiaru nieeksponowania autorskiego „ja”. To także świadoma, celowa i efektywna strategia. Dystans tożsamy jest nie tylko $\mathrm{z}$ rezerwą, blisko mu bowiem do powściągliwości, pozwalającej ostrożnie, $z$ rozmysłem, testować granice ekspresji. W debiutanckim tomie Świrszczyńska - rzadko ujawniając się jako podmiot liryczny wypowiadający się w liczbie pojedynczej - często oddaje głos podmiotowi zbiorowemu, „my”. Niekiedy też zwraca się do innych: „wy”, obie strategie oferują jej szansę formułowania sądów dotyczących ewentualnej przyszłości lub możliwość nakłaniania do działań.

Ponadto sacdzę, że bardziej interesujacca niż konstrukcja podmiotu mówiącego w liryce Świrszczyńskiej jest wizyjność, która Kazimierz Wyka nazwał „gobelinową” lub „witrażowa” ${ }^{27}$, co współgra $z$ upodobaniem poetki do szeroko pojętej malarskości. Nie zmienia to jednak faktu, że Wyka pisał też o tym, co uznał za zaletę, w tonie sugerującym, iż niekoniecznie podtrzymuje swoją opinię, albo, nieco inaczej, zdaje sobie sprawę z zagrożenia kryjącego się we wzmiankowanej wizyjności - określał ją mianem „bibułkowej i lampionowej fantastyki” ${ }^{28}$, przestrzegając, by nie przerodziła się w manieryczność. Faktycznie, misterna, ażurowa konstrukcja tomu Świrszczyńskiej początkowo może budzić obawy, że jej dekoracyjność przesłoni

Ibidem, s. 187.

Ibidem, s. 187-188.

Piątą z cech wymienionych przez Czechowicza są intertekstualne nawiązania do literatury francuskiej - głównie do poezji V. Hugo i P. Forta - możliwe do wychwycenia w metaforyce i w składni (ibidem, s. 188-189).

Ibidem, s. 188

K. Wy k a, Dwoje wizjonerów. W: Stara szuflada i inne szkice z lat 1932-1939. Oprac. M. U rb anow ski. Kraków 2000, s. 461.

Ibidem, s. 462. 
inne aspekty - ale nic bardziej mylnego. Nawet jeśli nieco przytłacza niemalże barokowa obfitość, nierzadko przechodzaca w groteskę, jak chociażby w lirykach Pochód, Ogród średniowieczny czy Południe ${ }^{29}$, kryje się w nich coś więcej niż tylko ozdobny nadmiar, a mianowicie rozważania eschatologiczne, namysł nad egzystencją, tematyka tanatologiczna. Wyka porównał teksty Świrszczyńskiej do układanki, „w której klocki mające się złożyć na obrazek rozmyślnie zostały zestawione niewłaściwymi bokami. Powstaje stąd symetryczny chaos, w proste linie uchwycony niepokój" ${ }^{30}$. Chociaż trudno pogodzić proste linie z groteskowymi krzywiznami wierszy Świrszczyńskiej, w przywołanym cytacie kryje się istotna sugestia: debiut zręcznej autorki utworów dla dzieci wymykał się kategoriom, stylom, poetykom, dykcjom, z którymi zwykle mieli do czynienia krytycy - o czym świadczyć może choćby interesująca metafora „symetryczny chaos” - był wyjątkowy, aktywował znane skądinąd Wyce elementy w zupełnie nowych zestawieniach. Co nie unieważnia konstatacji o tym, że poetka zgrabnie wmontowała w tomik właśnie np. dialog z awangardzistami, w konsekwencji uprawomocniając próby usytuowania jej w obrębie którejś z awangardowych linii, Juliana Przybosia lub Tadeusza Peipera. Ludwik Fryde przyporządkował Świrszczyńską do poetyki Przybosiowej, wskazując na odświeżający charakter stylu jego liryki:

Nowy styl w poezji nie jest tylko postulatem teorii. Jest już rzeczywistością.

Za prekursora jego należy uznać Juliana Przybosia. Nieprzerwana, piękna ewolucja artystyczna tego poety wyprowadziła go daleko poza granice poetyki Awangardy krakowskiej. W wierszach z okresu ostatniego dostrzegamy coraz pełniejszy triumf wyobraźni - czystego precyzyjnego rysunku i promieniującego blaskiem duchowym obrazu poetyckiego - nad materią empiryczną i psychiczną. Poeta „wygnaniec ptaków" - zdobywa wolność wewnętrzną i ponad koszmarem wizji eschatologicznej rozbija na krótką chwilę świetlistą tęczę, jakby nad światem ogarniętym przez potop wypuszczał gołębia do lotu.

Częściową lub pełną realizację nowa poetyka znalazła w sześciu książkach wydanych w ciągu ostatnich dwóch lat. Są to: nic więcej Czechowicza, Trzy zimy Miłosza, Wyprawy Zagórskiego, Tropiciel Rymkiewicza, Wiersze i proza Świrszczyńskiej i ostatnie w kolejności chronologicznej Obłoki wiosenne Piętaka ${ }^{31}$

Ta niedługa, acz trafna diagnoza sprawdza się w odniesieniu do debiutu Świrszczyńskiej bezbłędnie - skupienie na obrazie poetyckim, często zaskakującym inwencyjnością, traktowanie słów jako znaków nie wskazujących na konotowane przez siebie znaczenia, lecz daleko poza nie, bez wątpienia występują w poszcze-

Zob. A. Świrszczyńska, Południe (W 19):

Gotowały się góry,

drzewa oliwne śpiewały barzo cudnie.

Człowiek boży

przyszedł ku dziewkam u studniej.

Klaskały w ręce pagórki,

szklane gaje pieniły się $\mathrm{w}$ wietrze,

dziewkom $z$ kanarkowych włosów

kapie i brzęczy gęste powietrze.

Zielona ryba

patrzy okiem $z$ fryzowanej strugi,

30 Wy ka, op. cit., s. 461.

31 L. Fry de, Dwa pokolenia. W: Wybór pism krytycznych. Oprac. A. Bi er n a cki. Warszawa 1966, s. 210. Więcej na temat modelu liryki wypracowanego przez J. Przybosia zob. np. S. J a w or ski, Awangarda. Warszawa 1992, s. 114-115. 
gólnych lirykach i prozatorskich miniaturach autorki ${ }^{32}$. Awangardowość u Świrszczyńskiej czerpie również z postulatu ekwiwalentyzacji uczuć, sformułowanego przez Peipera, $z$ którego poetyką łączy ja jeszcze jedna istotna cecha, a mianowicie fascynacja kinem - widoczna chociażby w wierszach Pochód, Cyrk ${ }^{33}$, Wędrowcy oraz w prozach Na prowincji, W operze czy $O$ świcie ${ }^{34}$. Sa one swoistymi ujęciami filmowymi zatrzymanymi w wiecznym „teraz”, ciagle dzieje się w nich to samo. Ich prymarna statyczność, powolność jest złudzeniem, ponieważ stale powtarzana w nich historia/sytuacja nie zamiera ani na chwilę. Kończy się i ponownie zaczyna $\mathrm{w}$ tym samym momencie, teraźniejszość trwa w permanentnym zapętleniu.

Skojarzenia $\mathrm{z}$ kinem odsyłają również do następnej $\mathrm{z}$ awangardowych cech poezji Świrszczyńskiej, czyli do odblasków futuryzmu. Wiersze i prozy raz po raz rozbłyskuja zaczerpniętymi z futuryzmu dynamicznymi przedstawieniami, skoncentrowanymi na tematyce związanej z nowoczesnością, miastem, techniką. Najwięcej tego typu odniesień jest w drugiej części tomu, nie są one szczególnie spektakularne czy intensywne, cechuje je bowiem finezyjny liryzm, pewna subtelna impresyjność, ale i łagodna sensualność:

Kiedy o świcie wracamy $z$ balu,

przekupki niosa $\mathrm{z}$ hal fantastyczne kosze sielskich warzyw.

Znajdziesz tu sałatę i pachnące aromatycznie selery.

Policjant na spłukanej jezdni daje znaki autom, co powoli gaszą światła.

(Ranek $w$ mieście. W 25)

Podobnie, a jednocześnie odmiennie jest w liryku Cywilizacja, zaczynającym się tak:

\author{
Wielkie szlochające zespoły miast. \\ Cywilizacje pełne, przewlekłe, ociagające się \\ jak krok człowieka, którego stopę \\ cień zatrzymuje zarazem i uwypukla [W 28]
}

Zob. Fryde, op. cit., s. 462.

Zob. A. Świrszczyńs ka, Cyrk (W 27):

\author{
Ryżowłosy olbrzym \\ w czerwonych trykotach \\ jowialnie dźwiga \\ ciężary. \\ Płowe klaczki tańczą menueta, \\ ekstatycznie ceremonialne \\ jak rodzina młodych chińskich cesarzy. \\ Potem maszerują zapaśnicy. \\ Masywni, \\ kategorycznie piękni w świetle lamp.
}

skiej - zob. A. Świ r s zczyń s ka, O świcie (W 56):

„Blisko Nazaretu była święta studnia, do której nadobna pani Dulcynea o świcie przyszła po wodę, wiodąc za uzdę dwa przysadziste ogiery.

- Zimno tak boso - mówi w mroku rudy pachciarz i dźwiga na wózek bańki białego jak księżyc mleka.

- A zimno.

- I ciemno. To dopiero.

- E, jak ja, to ja się nie zgubię. Do krów albo po wodę. Dziesięć lat tak chodzę.

I podnosząc do góry potężne łokcie, poprawia chustkę na głowie.

A potem rozmawiają o koniach". 
- w którym dochodzi do zderzenia jednostki i miasta. Owa dość gwałtowana interakcja zostaje złagodzona przez personifikację - „szlochające miasta” - dzięki czemu zostaje postawiony znak równości między człowiekiem a cywilizacją, ich udziałem jest/będzie taki sam los. Futurystyczny $z$ ducha zachwyt nad światem, zmysłowość ${ }^{35}$ potrzebne są Świrszczyńskiej, aby złagodzić katastroficzną aurę tomu (do czego jeszcze wrócę), ponieważ akcentują żywotność, zaangażowanie w świat aż do emocjonalnego, mentalnego połączenia $\mathrm{z}$ nim - vide wiersz Taniec noca:

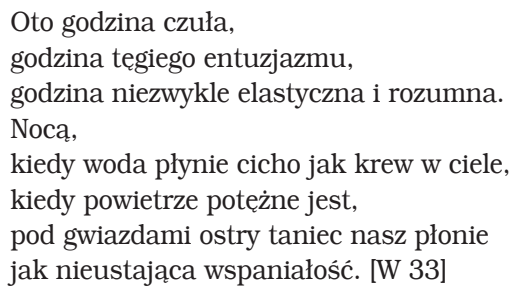

Kolejnym z (około)awangardowych oddźwięków w poezji Świrszczyńskiej jest lekkie, niemniej wyraźne echo surrealizmu, którego rozmyta „obecność” w polskiej poezji jako takiej była tyleż oczywista ${ }^{36}$, co w znacznej mierze problematyczna, gdyż trudna do jednoznacznego wskazania ${ }^{37}$. W monografii skoncentrowanej wokół wzajemnych oscylacji awangardy i nadrealizmu Stanisław Jaworski wymienił autorkę Wierszy i próz tylko raz, mało tego, nie w kontekście surrealistycznej poetyki, lecz awangardowej koncentracji na metaforze oraz konieczności oddzielenia liryki od prozy, by umożliwić słowom zyskanie nowych znaczeń ${ }^{38}$. Niemalże całkowita nieobecność poetki w przywołanej publikacji nie podważa sugestii, że w jej debiucie możliwe jest wyłuskanie niewielkich surrealistycznych odprysków, jakimi są oniryczne krajobrazy w wierszach z pierwszej i drugiej części, ich specyficzna fabularność, dynamiczność. Chociaż są to drobne sugestie, niewielkie szczegóły, nie można ich ignorować. Szukając śladów praktyki artystycznej czy literackiej kojarzonej z niezwykłością, kwestionowaniem przyzwyczajeń, zaskakującymi zestawieniami, Jakub Kornhauser właśnie warszawsko-krakowską poetkę wskazuje jako jej potencjalną realizatorkę:

Zob. J aw or s ki, op. cit., s. 29-30.

Zob. S. J a w o r s k i, Między awangardą a nadrealizmem. Główne kierunki przemian poezji polskiej $w$ latach trzydziestych na tle europejskim. Kraków 1976.

Zob. J. Kornhause r, Surrealizm w Polsce. Odtracona wyobraźnia - polska poezja zamiast surrealizmu. W: Awangarda. Strajki, zakłócenia, deformacje. Kraków 2017, s. 66-67: „Surrealizmu nigdy w Polsce nie było. I to jest tym ciekawsze, że surrealizmów było bez liku. Być może - wbrew pierwotnym intencjom swych promotorów - surrealizmy rozpierzchły się w rozmaitych kierunkach, przyjmując rozmaite formy i miana, kojarząc się z napotkanymi na swej drodze tworami, stale ewoluując i poszerzając zakres swoich zainteresowań. [...] Surrealizm oswobodził język z przyzwyczajeń, sam stał się nowym językiem odzwierciedlającym w pełni indywidualną wrażliwość. Surrealistyczna wrażliwość zaczęła funkcjonować jako sposób patrzenia na świat, przestawiania elementów rzeczywistości świata realnego, by zbudować swój własny, tym samym zacierała granice między snem a jawą, wyrazem a desygnatem, wyznaczała nowe obszary poszukiwań, budziła niespodziewane relacje między przedmiotami, ba, budziła do życia same przedmioty".

J a w or s ki, Między awangardą a nadrealizmem, s. 44. 
W latach trzydziestych pewne wątłe surrealistyczne tropy chyłkiem przemykają u Anny Świrszczyńskiej w tomie Wiersze i proza (1936), głównie w krótkich prozach poetyckich czy poematach prozą. Najbardziej tajemnicza jest u Świrszczyńskiej sama opisywana sytuacja, jak gdyby wycięta z całości, zastygła w ruchu, pozbawiona jakiegoś szerszego kontekstu. Realne przedmioty nabierają niepokojących cech, pojawiają się nieprzystające do obrazu rekwizyty - manekin, nożyczki, gwoździe, trzonek od młotka, zupełnie jakby uciekły z jakiejś innej opowieści. To za mało, aby przypisywać tym prozom poetyckim surrealistyczny charakter, ale jest o tyle ważne, że będzie miało swoją przekonującą kontynuację po wojnie ${ }^{39}$.

Przytoczony cytat zawiera nie tylko stwierdzenie pewnego literackiego faktu (odsyła również do prozy poetyckiej Zbrodnia, otwierającej trzecią część debiutu przyszłej autorki tak odmiennego w tonie zbioru Jestem baba), skłania, aby przyjrzeć się całemu tomowi - nie zaś jedynie zawartym w nim miniaturom prozatorskim - tak, jak patrzy się na obrazy zastygłe w kadrze filmowym czy na fotografie stanowiące część zaginionego cyklu. Wyjęte $z$ bliżej nie znanej całości (całości, której tak naprawdę nie było i nie ma, gdyż jest ona zbędna i świetnie zastępowalna przez fragment), są zagadkowe, intrygujące, fascynujące. Zaczynają bowiem funkcjonować jako autonomiczne artefakty, odsyłające nie tylko do siebie samych, lub, przeciwnie, gdzieś poza siebie, w przestrzeń licznych, niekoniecznie jasnych możliwości, zapełnioną oryginalnymi postaciami czy niestandardowymi przedmiotami, jak w szkicu Na spacerze:

Płaski powozik o wysokich kołach czesze aleją. Długie, wypukłe koniki mają wytworny kształt kształt motków jedwabiu.

U kragłej szyi damy błękitny szal gazowy trzepie się mrucząc, podczas gdy ona sama, wsparłszy głowę na ramieniu towarzysza, śni, że jest Eurydyką i ręką uspokaja lwy, zirytowane graniem oblubieńca. [W 44]

Lekkość obrazka, kreślonego w tonie nawiązującym do surrealizmu, zostanie w dalszej części tekstu zmieciona przez interwencję werystycznego opisu powozu i woźnicy. Niewykluczone, że sugerowana przez nadrealistyczne echa paradoksalna nieistotność czy też dziwna swojskość, lub właśnie niecodzienna inność, potrzebna była Świrszczyńskiej, po raz kolejny, do rozładowania napięcia wyczuwalnego w całym tomie, wywoływanego przez tematykę tanatologiczna, jak choćby w liryku Victoria, w którym powraca groza pobojowisk z pierwszej wojny światowej:

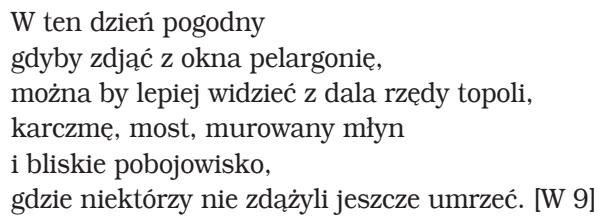

Niedługie wyliczenie elementów rozmaitych awangardowych poetyk $\mathrm{w}$ debiucie Świrszczyńskiej może sugerować, że chociaż doceniony, potraktowany jako znaczący, stanowi on w rzeczywistości swoistą antologię nawiązań. Oczywiście, autorka nie tworzyła w literackiej próżni i siłą rzeczy (oraz na mocy reguł wynikających $\mathrm{z}$ intertekstualności) przetwarzała znane jej skądinąd dykcje poetyckie. Niemniej 
tym, co, jak sadzę, najcenniejsze w jej debiucie, jest umiejętność łączenia rozlicznych aluzji biblijnych, mitologicznych, odniesień do sztuki średniowiecznej, barokowej z poetykami współczesnymi Świrszczyńskiej - nie tylko by nadać temu barwnemu amalgamatowi niezbywalną indywidualną sygnaturę, lecz także po to, aby dzięki nim móc pseudonimować pisanie o śmierci, zagrożeniu, nietrwałości, przepuszczalności granic światów istniejącego i wyimaginowanego.

W utworach zgromadzonych w pierwszej części tomu zaskakuje swoista nadreprezentacja śmierci, przewijającej się nawet w utworach pełnych ruchu, spokoju i pogody. Wyjściowy liryk - Dzień stworzenia - również zawiera przeczucie finalności, o którym mówi się wprost w kolejnych, np. „Będziemy wszyscy żywcem do raju wzięci / co do jednego" (Podróż. W 12), Ogród średniowieczny zamyka się końcem świata, Strumień wiosenny wieńczy takie stwierdzenie: „Wstępuje pochylając się / w wodę zimną i jędrną / jak w ostateczne uniesienie, / jak w śmierć" (W 16; nie do pominięcia jest także jego erotyczna wymowa). Dopiero dwa końcowe liryki - Groteska i Sielanka - wyciszają niepokój, zapewniając gładkie przejście do części drugiej zbioru, w której sporo jest impresji, więcej niż realistyczności w poprzedniej, dużo witalistycznej dynamiki. Emocje wybuchaja, szybko i finezyjnie sa też tonowane - jak w liryku Po majówce:

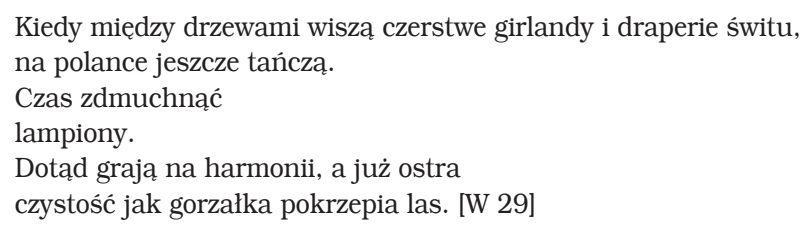

Wszystkim, zdecydowanie, konsekwentnie, acz bez gwałtowności, zarządza Czas z Kwitnacego drzewa. Ostatnia część tomu jest wyjątkowa nie tylko dlatego, że dokonuje się w niej wyraźna zmiana genologiczna - lirykę zastępuje proza, lecz także dlatego, iż pojawia się w niej cała galeria postaci kobiet, w tym: zamordowana krawcowa; właścicielka restauracji; kobieta w powozie; dojarka; mitologiczna piękna Helena - której smutny los zwiastuje nieubłagana Ananke; Walkiria; królewska faworyta; Dulcynea; pani aptekarzowa - Rozalia, która, jak przyznaje, nie wyszła za mąż z miłości. Mniej lub bardziej prawdopodobne historie są niemalże małymi, lirycznymi reportażami, dziejącymi się w nie do końca rzeczywistych, baśniowych, niby biblijnych, czasami złudnie realistycznych przestrzeniach ${ }^{40}$. Swirszczyńska wychodzi więc od uwag ogólnych, od refleksji niemalże eschatologicznych, by przejść do opisów specyficznej, frapującej codzienności i w końcu skupić się na pojedynczych bohaterkach, których los przeważnie naznaczony jest jakąś nieusuwalna skazą. Mam wrażenie, że cały tom to nieprzerwane pseudonimowanie nastrojów raczej ciemnych i pesymistycznych, mimo ich pozornej wielobarwności, bogactwa, dynamiki.

Od zachwytu po przerażenie i rezygnację - tak z grubsza przebiegała linia rozwojowa awangard w Dwudziestoleciu międzywojennym. Bardzo podobnie ukształ-

40 Zob. A. Świrs zczyńs ka, Podwieczorek (W 64): „Czy widzicie ten balkonik, mały i mocny jak orzeszek? Dziś pełen jest gości. Są to przeważnie młodziutkie damy z kibiciami cienkimi od gorsetów, z sterczącymi grzywkami. Czysty wiatr rusza pasiaste falbanki parasoli”. 
towany jest debiutancki tom Świrszczyńskiej. Nawiązania do tradycji zapewniaja chwilowy oddech od współczesności, natomiast archaizacje, groteska, surrealność, witalizm maskują grozę spodziewanej katastrofy. Anna Legeżyńska lokuje Wiersze i proze w obrębie „tradycji awangardowo-imażynistyczno-nadrealistycznej” ${ }^{41}$. Poetka w debiutanckim zbiorze proponuje kolaż, w którym proporcje między poszczególnymi elementami co chwila zmieniają się, uwypuklając jedne kosztem wytłumiania innych. Wśród nich raz po raz pojawiają się oddźwięki awangardowe.

\section{Abstract \\ ANNA PEKANIEC Jagiellonian University, Cracow \\ ORCID: 0000-0001-7516-1413}

\section{AVANT-GARDE RESPONSES ANNA ŚWIRSZCZYŃSKA'S POEMS AND POETIC PROSE OF THE 1930S}

The paper concentrates on Anna Świrszczyńska's debut book; precisely on attempts to discuss its complex structure, combinations of various poetics, recurrent motifs. The collection, composed both of lyric sensu stricto and of poetic prose, is an interesting amalgamate of avant-garde, catastrophic, and surrealist trend (though rather employing the surrealist achievements). Important in the analysed pieces is also an indication of the role played by the art, oftentimes cloaked with the atmosphere of vitalism-so close to the Skamander diction. Bearing in mind that the poetess belonged to so-called Generation 1910, her peculiar distinctness, functioning outside literary groups, as well as her deriving from tradition and from the literary trends contemporary to her, the author of the article extracts the specificity of Świrszczyńska's successful and mature debut in which parallel to dynamism one discerns darker tones indicating that her lyric collages were not only beautiful, but also referred to non-literary contexts: they stuck in catastrophic moods felt three years before the outbreak of the World War II.

41 A. Le ge ży ńs k a, Ewolucja liryki Anny Świrszczyńskiej. W zb.: Przez znaki-do człowieka. Red. B. Sienkiewicz. Współpr. A. Legeżyńska, W. Wielopolski. Poznań 1997, s. 103. Badaczka dodaje również, że „utwory tu zebrane wiele mają wspólnego z estetycznymi uwrażliwieniami europejskiej i polskiej awangardy (poematy prozą M. Jacoba; liryka Czechowicza)” (ibidem). 